\title{
Challenges of Channel Conflicts Management in Soft Drink
}

\author{
Ehikwe A.E. ${ }^{1}$, Egboro Felix .O. ${ }^{2}$ \\ Department of Marketing; \\ Faculty of Business Administration, University of Nigeria, Enugu Campus \\ angrede2006@yahoo.com \\ Department of Business Administration, \\ Delta State Polytechnic, Otefe Oghara, Delta State.
}

\begin{abstract}
Producing products that customers want, pricing them correctly and developing well - designed promotional plans are necessary but not sufficient conditions for customer satisfaction. The final part of the Jigsaw is distribution, the place element of the Marketing Mix. Products need to be available in adequate quantities, in convenient locations and at the time when customers want to buy them. Producers need to consider not only the needs of their ultimate customers but also the requirements of channel intermediaries, those organizations responsible for facilitating the distribution of products to customers. When producers and channel members are independent, inevitably conflict occurs from time to time. The intensity of conflict can range from occasional, minor disagreements that are quickly forgotten, to major disputes that fuel continuous bitter relationships. This paper focused on the challenges of channel conflicts management in soft drink industry with particular reference to coca-cola. The paper x-rayed the channels of distribution, generally and specifically in coca-cola; causes of channel conflicts and conflict resolutions. Recommendations were made on how best channel conflicts could be resolved through partnership approach, market partitioning, co-operation and adoption of super ordinate goals.
\end{abstract}

KEYWORDS: Channel Conflicts, Management, Soft Drink Industry

\section{Council for Innovative Research}

Peer Review Research Publishing System

Journal: International Journal of Management \& Information Technology

Vol. 9, No. 1

editor@cirworld.com

www.cirworld.com, member.cirworld.com 


\section{INTRODUCTION}

In today's global competition, companies use multiple channel strategy for various reasons, especially the intense global competition that has compelled the use of multi-channels for product movements through two or more channels of distribution, (Webb and Hogan, 2002). The reasons for the adoption are the need to increase market share, cut costs, cover different marketing segments, and meet competitive challenges and the differences in consumer behaviour (Sa Vinhas and Anderson, 2005). The dilemma though, seem to be that decision makers are trapped between introducing new channel members that meet new trends and the challenges of "channel conflicts" generated as a result of adding new channels, especially from old traditional distributors. In the submissions of Moriarty and Moran (1990), maximized profits and increased customers exposure are important, as well as access to a marketer's offering and increased sales volume (Kumar \& Venkatesan, 2005), and market presence (Sharma and Mehrotra, 2007). The payoff of such advantages, however, could be eroded by "channel conflict" leading to decreased sales.

Conflicts have been studied from a variety of perspectives drawn from different disciplines including psychology, sociology, economics, political science, management and marketing (Lewieki, Weiss and Lewin, 1992). Research in marketing channels has a tradition of focusing on conflict and power as key constructs influencing distribution (Kuman, and Stern, 2001, Vosgerau, Anderson, and Ross, 2008). Channel conflicts are situations in which one channel member perceives another to be engaged in behaviour that impede the achievements of set goals (Sterm, Ansary and Coughlan 1996).

The conflict resolution strategies of the members vary (Thomas 1992), as the strategies used by the parties to resolve conflict will either improve or reduce the quality of the relationships among channel members. Sharama and Mehrota (2007) proposed a model for "choosing an optimal channel mix in multi channel environments", that includes a multichannel strategy process of six steps, namely; to develop strategic multi-channel objectives; understand customer and channel touch points to leverage advantage; undertake a review of industry structure and channel options; undertake channel usage pattern; review channel economy; and develop an integrated channel management strategy. The model is a good mathematical model based on the profits of each channel, but it is a business to business model, designed for service companies and cannot be applied on consumer product and wholesales business because the case in consumer products is very different. (Rosenbloom 2007).

This paper examine the challenges of channel conflict management with emphases on causes, types, impact and resolution strategies of channel conflict taking coca-cola as reference point or case study.

\section{Statement of the Problem}

The key to effective motivation is to understand the needs and problems of market intermediaries (Jobber, 1998). Conflict may result from the absence or little of these motivators arising from differences in goals, poor performances, domain dissention, differing perceptions of reality, and maximization of profit goals. The information flow and exchanges between the manufacturers and the intermediaries could be very poor, narrow, and personified that commercial and business information may be very dry and possibly non-existent (Ehikwe 2002). Channel members may want to mix their product lines from different manufacturers who may expect maximum attention to their individual products in order to optimize sales.

Manufacturers also by-pass the intermediaries to deal directly with consumers especially in situations of intensive and selective distribution strategies, with Coca cola intensively selling to individual consumers with crates thereby, undercutting the effort of the middlemen (Ehikwe, 2002). There are reasons to determine the extent to which differences in goals, multiple distribution channels, manufacturers' by-passing middlemen, difference in desired product lines, may impact on channel conflicts and what possible strategies can be used for channel conflict resolution? These are the nexus of this study.

\section{Objectives of the study}

The following objectives are imperative:

1. To examine possible causes of channel conflict including differences in goals, desired product lines, multiple distribution channels, and lack of market information.

2. To determine the extent to which channel conflict contributes to organization growth and development if any.

3. To examine the extent to which partnership approach, middlemen training, market partitioning, channel ownership and coercion reduces channel conflicts.

4. To examine the impact of multi-channel environment on customer loyalty.

\section{Research Question}

The research questions were designed to further deepen the investigation based on the objectives to explore areas that required to be explained. The responses to these questions will illuminate the grey areas for better understanding of the phenomenon.

1. What extent do differences in goal, desired product lines, multiple distribution channels, lack of market information flow causes channel conflict?

2. To what extent does channel conflict contribute to organization growth and development? 
3. To what extent does partnership approach, middlemen training, market partitioning, channel ownership and coercion reduces channel conflicts.

4. What is the impact of multi-channel environment on customer loyalty?

\section{REVIEW OF LITERATURE}

\section{Conceptual Framework}

\section{Coca - cola Historical Background and Operational System}

Dr. John Pemberton, a pharmacist from Atlanta, invented coca-cola in 1886. 'The world's largest non-alcoholic beverage company trademarked its name and logo in 1893. After thirty years of establishment, the company went public in 1919. The share price of its initial public offering was $\$ 40$ a share (Data monitor, 2012). Coca-cola is currently available in more than 200 countries and reaches about $99 \%$ of the world population. Consumption rate of trademarked or licensed products amount to 1.7 billion servings a day, and as at December $31^{\text {st }} 2010$, the company has 139,600 employees worldwide (The coca - cola company, 2011).

Coca-cola views everyone as potential consumers. Coca-cola targets all age groups; however, the one with most potential is the age group between 18 to 25 years old, which tends to have busy lifestyles. Furthermore, the company attempts to appeal students and family - oriented consumers. The socio-economic status of these demographics ranges from lower to upper-lower income level (Grimm, 2000).

According to National Geographic (2011), the beverage is made with 90 percent water. Because water's taste varies at every location, coca-cola has to neutralize the water to ensure that its products taste consistently worldwide. The other main ingredient is high fructose corn syrup (HFCS) and since imported sugar is more expensive, coca-cola uses HFCS as its principal sweetener. Today, the brands that are most often quoted as being standardized are Coca cola and Levi Strauss, (Jobber 1989). Coca-cola is the largest player in the non-alcoholic beverage industry. It operates in over 206 countries and has 900 bottling plants and factories worldwide with location such as Eurasia, Africa, Europe, Latin America, as well as North America (National Geographic 2011).

Coca-cola has the world's largest distribution systems, hence, it is able to reach almost every region (coca-cola co, 2011). The company distributes its beverages to consumers through various retailers, wholesalers, vending machines, and distribution centers. Furthermore, it sells its syrup and concentrates to cages and restaurants used in fountain drink dispensers, ("Coca-cola raises", 2011, Staff, 2010). Overall, coca-cola uses the social media for community engagements and also to reach out to more consumer, the company takes branding seriously and tackles every global venture strategically by adapting to local cultures, (Wooten, 2011).

Table 1: Coca-Cola SWOT Analysis

\section{Strategic Issues in Conflict Management}

\section{Strengths:}

Strong brand image and customer loyalty

- $\quad$ Robust global infrastructures and distribution system.

Various product offerings

- $\quad$ Solid financial condition and market presence.

Opportunities:

- Expand to other developing countries

- Offer new beverages / drinks

- Shift focus to volume / price

Weaknesses:

High fixed cost of business

Several product recalls

Higher prices compared to others.

Threats:

- $\quad$ Change in customer preferences.

Global economic recession

Foreign exchange fluctuations.

Source: Wang, (2008) study: Coke, the most talked about brand in America.

\section{Porter's Five Forces for Soft Drink Industry.}

\section{Threats of new entrants (low):}

H: $\quad$ Low switching cost for buyer, low product differentiation

L: $\quad$ High economies of scale, High capital requirement, low access to distribution channel.

Power of Buyers (Moderate - High):

H: $\quad$ Low switching cost for buyer, moderate product differentiation for supplier.

L: $\quad$ Low purchase volume for buyer, Low threat of backward integration. 
Power of Suppliers (High):

H: $\quad$ High switching cost to another supplier, high supplier's concentration, Low availability for product substitute.

L: $\quad$ High importance of customer, Low threat of forward integration.

Threat of Substitute Product (Moderate - High):

H: $\quad$ High differentiation of Substitute product

L: $\quad$ Low price performance relationship.

Intensity of Rivalry (Very High):

H: $\quad$ High number of Competitors, Low Industry Growth Rate, High Fixed cost and strange cost, low switching cost for buyers. High exits barriers.

$L:$

none.

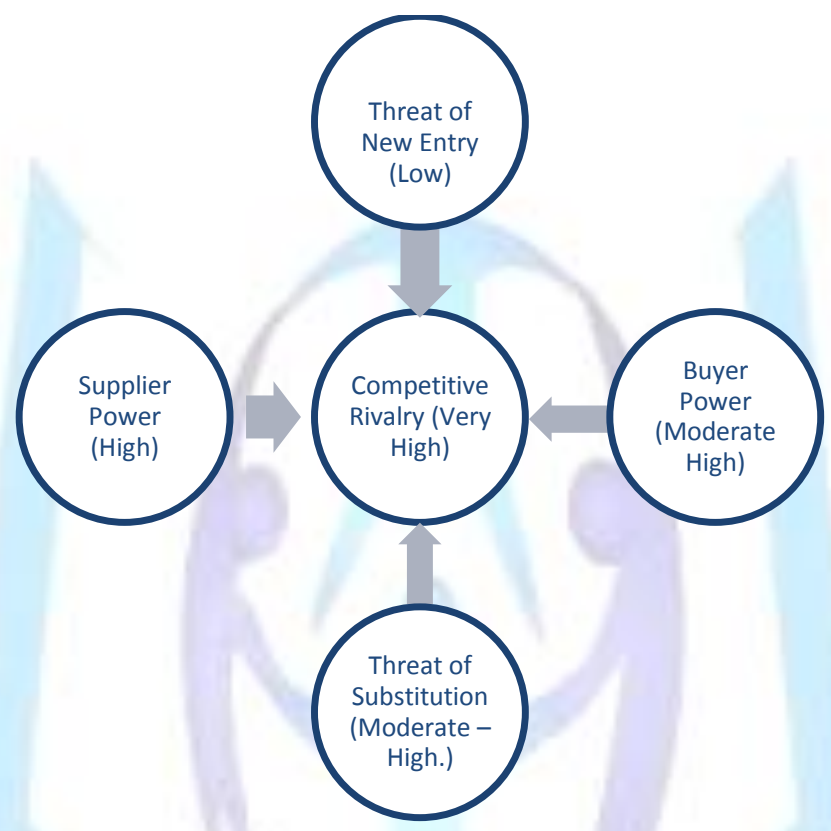

Fig 1: Poter's five for Soft Drink industry.

Source: Wang, (2008) study: Coke, the most talked about brand in America

\section{Channels of Distribution in Perspectives}

Distribution channels are set of "inter-dependent organizations involved in the process of making a product or service available for use or consumption" (Coughlan, Anderson, Stern and El-Ansary 2006). The marketing intermediaries or institutions are the backbone of the manufacturers and the cornerstone of the consumers. They ensure that manufacturers who cannot get their products to consumers and consumers who cannot buy in bulk from manufacturers are satisfactorily and adequately served. The manufacturers provide the needed incentives to seek cooperation of the market intermediaries by motivating them through provision of various facilities, (Ehikwe 2002:230).

Decisions regarding the structure of the marketing channel and choice of number and type of distribution intermediaries have been traditional, (Cannon and Perreault, 1999). In recent years, there has been a surge of interest in the study of channel relationships, (Sheth and Parvatiyar, 2000, Palmatier, Fant, Grewal and Evans, 2006).

The market activities in the channel are pricing, sales, advertising and promotion, transportation and logistics as well as product strategy through branding, policies, willingness to stock and customizes profits, install, maintain and offer credit, all to enhance value added, (Palmatier et al., 2006, Koltler and Armstrong, 2004, Narayandas, Caravella, and Deighton, 2002). According to Kotler and Armstrong (2004), channels are the different flows with complex systems where customers and firms interact and satisfy their objectives respectively, thus, there exist direct deliveries to customers and indirect marketing channels that use wholesalers and retailers. These may bring dissatisfaction and consumer confusion as inter-organizational relationships are prone to conflict for opposition or incompatibility of goals, (Thomas, 1992). Conflict in channels has been defined as "a situation of suspicious behavior among members. The need for distribution channels according to Abusaleh and Yunus, 2007, is to enable large companies use intermediaries for the business of manufacturing and marketing, turning out tens of thousands of cases of soft drinks, as the distribution chain is readily handy that may create a pull and push effects, (Aguezzoul 2007, Chwen, et al., 20). There are long and short channels for consumer, industrial and service goods, (Gunasekarana 2004, Rabinovich and Bailey 2004). In the contributions of Jobber,(1989), channel links are through direct deliveries to customers and indirect through agent, brokers, jobbers, wholesalers, distributors, retailers to the consumers. 


\section{Factors Considered in Channel Selection.}

The general considerations in channel planning and selection according to Peter and Donnelly, (2004) are customer characteristics, product characteristics, intermediary characteristics; competitor characteristics, company characteristics and environmental characteristics.

\section{Table 2. General Consideration in Channel Planning}
1) Customer Characteristics
a) Number
b) Geographic Dispersion
c) Preferred Channels and Outlets for purchase
d) Purchasing Patterns
e) Use of new Channels (e.g. online Purchasing)

\section{2) Product Characteristics}

a) Unit Value

b) Perishability

c) Bulkiness

d) Degree of Standardization

e) Installation and Maintenance Services required

3) Intermediary Characteristics

a) Availability

b) Willingness to accept product or product line

c) Geographic market served

d) Marketing functions performed

e) Potential for conflict

f) Potential for long-term relationship

g) Competitive products sold

h) financial condition

i) Other strengths and weaknesses

4) Competitor Characteristics.

a) Number

b) Relative size and market share c) Distribution channels and strategy

d) Financial condition and estimated marketing budget.

e) Size of product mix and product lines

f) Overall marketing strategy employed

g) Other strengths and weakness

5) Company Characteristics

a) Relative size and market share

b) Financial condition and marketing budget

c) Size of product mix and product lines

d) Marketing strategy employed

e) Marketing objectives

f) Past channel experience

g) Marketing functions willing to perform

h) Other strengths and weaknesses

6) Environmental Characteristics.

a) Economic conditions

b) Legal regulations and restrictions

c) Political issues

d) Global and domestic cultural differences and changes

e) Technological changes

f) Other opportunities and threats.

Fig.3 General consideratiosn in channel planning

Source: Peter, P. J., and Donnelly, J.H. (2004) Marketing Management Knowledge and skills, New York, McGrawHill companies.

Based on the above characteristics, the choice of channels can be further refined in terms of distribution coverage required, degree of control desired, total distribution cost and channel flexibility, (Deleersnyaher et al., 2002; Falk, et al., 2007, Geyskens, Gielens and Dekimpe 2002, Balasubramanian, et al 2005,Neslin et al., 2006, Rangaswamy and Van Bruggen 2005).

\section{Conflict Perceptions of Channel members}

Pondy (1967) identified five stages of a conflict including Latent, perceived, felt, manifest and aftermath, as Gaski (1984), argues that these stages present a perceptual and a behavioural dimension of conflict. A channel member's perceptions of other member's actions will be based on normative, rational / instrumental, and emotional reasoning (Thomas, 1992). Perceptions of conflict based on normative reasoning consider "the goodness of the act itself - that is, its, normative acceptability" (Thomas, 1992). The perception of conflict by channel members could be positive, negative, or rational instrument to consider the desirability of the likely outcomes of a course of action that determine their interests. Conflicts perceptions based on emotional reasoning considers the emotions generated during a conflict episode as well as emotions left over from other events (Thomas 1992).

Causes of Channel Conflicts 
The submissions of Stern and El-Ansary (1992), Jobber, (1989); Kotler and Keller (2009), Anderson and Narcus 1990), all identified the causes of channel conflicts as goal Incompatibility, difference in desired product lines, multiple distribution channels, inadequacies in performance, unclear roles and right, differences in perception, and intermediaries dependence on the manufacturers. According to Gold Kuhi, (2005), Magrath \& Hardy (1989), in order to manage channel conflict, it is required to validate the reality of the conflict.

In Rolnicki (1988) submissions some reasons channel programs may fail are ignoring end user buying patterns and needs, having two approaches to the channel, expecting channels to change ordinarilly, distributors reluctance to move out of their comfort zone, sticking with traditional channels too long, not realizing or building your importance (or lack therefore) to the channel, being casual about selecting and evaluating your distributors, dealers and representatives and not understanding the economic of channel marketing, avoiding channel conflict instead of accepting and managing it and above all these, channel conflict will not go away. In keeping track of reported issues, organisation can create insight into the existence of channel conflicts management needs and establish which level of conflict is acceptable (Bendix et al 2001), perceived, and managed properly, (Coughlan et al., 2001, 2006).

\section{Channel Conflicts in Distribution}

Channel conflict stems from the situation in which one channel member perceives another channel member to be engaged in behaviour that are inimical to the achievement of set goals (Stern, Ansary and Coughlan 1996, Goldkuhi 2005).Vertical channel conflicts means conflict between different levels within the same channel, which will be the case if a manufacturer adds a direct marketing channel next to existing marketing channels. Horizontal channel conflict is conflict between members at the same level within the channel. Multi-channel conflicts exist when the manufacturer has established two or more channels that sell to the same market. It is likely to be especially intense when the members of one channel get a lower price (based on larger-volume purchases) or work with a lower margin, (Bradford, et al 2004).

\section{Channel Conflicts on Organization Growth and other Institutions}

Channel conflict is often seen as harmful and unwanted for the growth of a company, but there are some channel conflicts which can benefit a company and in its developing process (Sa Vinhas, and Anderson 2005), that is, the "functional" channel conflict. Companies lacking reasonable channel conflicts may be passive and lacking innovation. Some positive channels conflicts can force channel members to make effort and try to create new opportunities, Moriarty and Ursula, (1988).

The major cost of channel conflict which manufacturers have to bear is weakening the relationship with the distribution channels, (Rosebloom, 2007) especially the reseller as one of the factors which help the manufacturers to achieve success, (Palmatier et al 2006), and according to Gaski, (1984), channel partners ultimately own the end customer relationship between the retailers and customers. Cannon and Perreault (1999) pointed out that using e-channel and removing the intermediaries can help the manufacturers to improve the efficiency of supply chain but manufacturers have to carry on functions and roles of retailers, as Dant and Schul (1992) state "we can eliminate the intermediaries but we cannot remove their functions". In Hibbard, et al., (2001) it is not cost-effective for manufacturers to provide value-add support to customers, and therefore, have to take into consideration the benefit they can earn from adding new channel and the cost of carrying out the roles of retailers as well as the cost of losing potential market size and providing the value-add services, (Brown and Day (1981). Resellers reduce or stop taking and carrying products from companies who are building up their direct outlets (Stern, El - Ansary and Coughlan 1996).

\section{Channel Conflict Resolution Strategies}

As Jobber, (1998) identified six channel conflict resolution strategies in developing a partnership, training in conflict handling, market partitioning, improving performance, and channel ownership, coercion, Dant and Schul (1992) suggests four, namely; problem solving, persuasion, bargaining, politics, while Kotler and Keller, (2009) identify six; namely; through adoption of super-ordinate goals, exchange of employees, joint membership in trade association, cooperation, diplomacy, mediation or arbitration and legal recourse. However, common goals are readily apparent to both parties. Information exchange, concessionary behaviour, and identification of new alternatives are likely (Pruitt, 1981).

\section{Distribution Channels used by Coca-cola}

(Grimn, 2001). Coca-cola has the world's largest distribution (coca-cola co, 2011). The company distributes its beverages to consumers through various retailers, wholesalers, vending machines and distribution centers. Furthermore, it sells its syrups and concentrates to cafes and restaurants used in fountain drinks dispensers. A vertical marketing, contractual and corporate systems relationship may be the result (Vereercke and Muylle 2006, Venus, et al., 2009, Wang and Archer 2007, Muhwezi, 2008). A horizontal marketing company may occur in which the companies might work with each other on a temporary or permanent basis or create a joint venture company, (Sheth and Paroatiyer 2000). Coca-cola, licenses bottlers (wholesalers) in various markets that buy syrup concentrates and then carbonate, bottle and sell it to retailers in local markets as a manufacturer - sponsored wholesaler franchise (Kotler and Keller 2009:468, Palmatier, et al., 2006) ). In fact, this is a contractual vertical marketing system, (Anderson and Narus,1990). The manufacturers will require the use of intensive distribution strategy where there will be need to put the products at the doorstep of every consumer through multi-channel services, (Ehikwe, 2002), through use of all institutions. 


\section{METHODOLOGY}

The study used survey design and ex-post facto in determining the factor responsible for channel conflicts in soft drinks with focus on coca-cola. The population of study consists of coca-cola distributors including retailers (Kiosk) wholesalers (Mini Depots) and salesmen in Sapele, Warri, Ughelli metropolises of Delta State of Nigeria. The estimate of the population is 1,800 intermediaries. A representative sample of $10 \%$ of the population of middlemen was used based on judgmental decision given a total of 180 intermediaries. The structured questionnaire was developed along a modified Likert - type scale of Strongly Agree (SA), Agree (A), Disagree (D) and Strongly Disagree (SD), to indicate the extent to which they agree or disagree with each of the items. The items in the structured questionnaire were weighted 4, 3, 2 and 1 points respectively, for the strongly agree, agree, un-decided, disagree and strongly disagree. Data were analyzed with descriptive statistics, using mean and standard deviation. Any mean rating which is 2.5 and above is considered a significant factor responsible for channel conflict.

This also applied for factors considered as conflict resolution strategies. Any mean rating below 2.5 is considered an insignificant factor or variable.

Table 3: Mean Rating on Specific Factors Responsible for Channel Conflict.

\begin{tabular}{|c|c|c|c|c|}
\hline S/No. & Items & $\begin{array}{l}\text { Mean } \\
\text { Rating }\end{array}$ & $\begin{array}{l}\text { Standard } \\
\text { Deviation }\end{array}$ & Remark \\
\hline 1. & $\begin{array}{l}\text { By-passing middleness by selling in creates to consumer's leads to } \\
\text { channel conflict in coca-cola. }\end{array}$ & 2.90 & 4.23 & Significant \\
\hline 2. & $\begin{array}{l}\text { Addition of different product lines by distributor which is seen as } \\
\text { disloyalty leads to channel conflict in coca-cola. }\end{array}$ & 1.93 & 12.04 & $\begin{array}{l}\text { Not } \\
\text { Significant }\end{array}$ \\
\hline 3. & $\begin{array}{l}\text { Differences in goals by way of profit maximization by distributors, } \\
\text { which affect sales volume leads to channel conflicts in coca-cola }\end{array}$ & 2.68 & 3.90 & Significant \\
\hline 4. & In adequacies in performance by middleness leads to channel conflict & 1.90 & 12.79 & $\begin{array}{l}\text { Not } \\
\text { Significant }\end{array}$ \\
\hline 5. & $\begin{array}{l}\text { Intensive distribution system (Multiple distributor channels) leads to } \\
\text { channel conflicts in coca-cola. }\end{array}$ & 2.90 & 8.47 & Significant \\
\hline 6. & $\begin{array}{l}\text { Unclear roles and right among intermediaries lead to channel conflict } \\
\text { in coca-cola distribution. }\end{array}$ & 2.50 & 0.21 & Significant \\
\hline 7. & $\begin{array}{l}\text { Differences in perception away middlemen and coca-cola company } \\
\text { leads to channel conflict. }\end{array}$ & 2.32 & 3.74 & Significant \\
\hline 8. & $\begin{array}{l}\text { Too much dependent on the manufacturers by intermediaries leads to } \\
\text { conflict. (lack of channel autonomy) }\end{array}$ & 2.94 & 9.41 & Significant \\
\hline 9. & $\begin{array}{l}\text { Lack of motivations inform of training leads to channel conflict in coca- } \\
\text { cola distribution system }\end{array}$ & 2.32 & 3.74 & $\begin{array}{l}\text { Not } \\
\text { Significant }\end{array}$ \\
\hline 10. & $\begin{array}{l}\text { Differences in information availability leads to channel conflict in soft } \\
\text { drink industry }\end{array}$ & 3.31 & 17.10 & Significant \\
\hline 11. & $\begin{array}{l}\text { Lack of constant communication between the manufacturers and the } \\
\text { channel member about new products leads to channel conflict }\end{array}$ & 2.71 & 4.37 & Significant \\
\hline 12. & $\begin{array}{l}\text { Competition for sarce resources e.g. limited availability of a new } \\
\text { product leads to channel conflict }\end{array}$ & 2.70 & 4.23 & Significant \\
\hline
\end{tabular}

Table 4: Mean Rating on Specific Strategies of Channel Conflict Resolution.

\begin{tabular}{|l|l|l|l|l|}
\hline S/No. & Items & $\begin{array}{l}\text { Mean } \\
\text { Rating }\end{array}$ & $\begin{array}{l}\text { Standard } \\
\text { Deviation }\end{array}$ & Remark \\
\hline 1. & Adoption of super ordinate goals leads to conflict resolutions. & 2.70 & 4.23 & Significant \\
\hline
\end{tabular}




\begin{tabular}{|c|c|c|c|c|}
\hline 2. & $\begin{array}{l}\text { Joint membership in trade association is an aubitode to channel } \\
\text { conflict. }\end{array}$ & 2.67 & 3.66 & Significant \\
\hline 3. & Co-optation leads to conflict resolution. & 2.63 & 3.66 & Significant \\
\hline 4. & Diplomacy, mediation or arbitration helps in channel conflict resolution & 2.94 & 9.41 & Significant \\
\hline 5. & $\begin{array}{l}\text { Legal recourse is one of the best approach to channel conflict } \\
\text { resolution. }\end{array}$ & 2.41 & 1.86 & $\begin{array}{l}\text { Not } \\
\text { Significant }\end{array}$ \\
\hline 6. & Coercion resolve channel conflicts in coca-cola & 2.11 & 8.27 & $\begin{array}{l}\text { Not } \\
\text { Significant }\end{array}$ \\
\hline 7. & Training of Middlemen is a good strategy in channel conflict resolution & 3.27 & 16.25 & Significant \\
\hline 8. & Marketing partitioning helps in resolving channel conflict & 2.55 & 1.07 & Significant \\
\hline 9. & $\begin{array}{l}\text { Channel ownership is a good strategy in conflict resolution in coca- } \\
\text { cola }\end{array}$ & 2.44 & 1.38 & $\begin{array}{l}\text { Not } \\
\text { Significant }\end{array}$ \\
\hline
\end{tabular}

\section{DISCUSSION OF FINDINGS}

The data analyzed showed that channel conflict resulted from by-passing middlemen to consumers, differences in goals in relation to profit maximization, intensive distribution, unclear roles and rights among intermediaries, too much dependence on manufacturers by intermediaries, different information availability, lack of constant communication, and competition for scarce resources such as new product.

On the other hand there is little or no conflict as a result of the presence of different product lines such as 7up in the channel, as well as inadequate performance by middlemen. The differences in perception on quality as per the result of our analysis do not lead to conflict as it is standardized. This is likely to be as a result of the fact that there may be no different in perception about the quality of coca-cola, in as much as is standardized. The analysis also reveal that lack of motivation does not bring conflict in as much as coca-cola are good in giving out coolers, fridges, etc. as motivation.

There is no significant relationship between coercion and conflict resolution. This means that there is little or no positive result when coercion is used to resolve conflict. In the same vein, litigation (law suite) is not an effective strategy in conflict resolution. Developing partnership approach, marketing partitioning, adoption of super ordinate goals, co-optation, diplomacy and arbitration, encouragement of joint membership in trade association all have significant relationship with conflict resolution. In other words, they are good strategies of resolving channel conflict. This is in line with Jobber (1998); Kotler and Kelly (2009).

\section{SUMMARY AND CONCLUSION}

Coca-cola views everyone as potential consumer. Coca-cola targets all age groups. It standardizes its product according to the climate condition of each country. It has an intensive distribution system or a multichannel system in which the product is made available at each doorstep. The major causes of channel conflict in coca-cola drink and associated soft drinks are differences in goals, by-passing of middlemen, unclear roles and right, competition for scarce reserves such as new products, etc.

Channel conflict is seen as harmful and unwanted for the group or a company. However, there are some channel conflicts which can benefit a company in its developing process. Company lacking reasonable channel conflict may be passive and lacking in innovation.

\section{RECOMMENDATIONS}

Coca-cola and similar soft drink companies should increase their motivational strategies in giving coolers, fridges, and promotional campaigns for middlemen, avoiding use of law suit in conflict resolution that can compel intermediaries' team up with competitors to introduce aggressive and offensive marketing or use of word-of-mouth to discredit the product to consumers. Coercion should be done with care as the distributor or retailer is a free moral agent who can decide to abandon the product entirely for something else. Increased market coverage in rural areas they cannot assess is important and to increase their market.

\section{REFERENCES}

[1] Abu Saleh, M and Yunus, M.A. (2007) Factors affecting commercial and Industrial Importers trust and commitment and their performance outcome in an Asian context, International Journal of Business Research $25,50-53$. 
[2] Aguezzoul, A (2007) The third party logistics selection: A review of Literature. International Journal of Logistics and supply chain congress 16, 297 - 334.

[3] Ancarani, F and Venkatesh, S (2004) "Price Levels and Price Dispersion within and Across Multiple Retailer Types Further Evidence and Extension", "Journal of the Academy of Marketing Science", 32, 176 - 187.

[4] Anderson, J. C and Narus, J. A. (1990). A Model of Distributor Firm and Manufacturer Firm Working Partnerships, Journal Marketing, 54, 42 - 58.

[5] Ansari, A. Mela, C. F and Scott, A. N (2008) "Customer Channel Migration", Journal of Marketing Research, $45,60-76$.

[6] Balasubramanian, S. Rjagopal, R, and Vijay, M. (2005) Consumers in A Multichannel Environment: Product Utility, process utility and Channel Choice". Journal of Interactive Marketing 19, (2) 12 - 30.

[7] Bendix, B. W. Goodman, J. B and Nunes, P. F. (2001), "Mapping the Way to Overcoming Channel Conflict, Chicago, Accentures Publishers.

[8] Bradford, K. Stringflow, A and Barton, A (2004) "Managing Conflict to Improve the Effectiveness of Retail Networks". Journal of Retailing, 80; 181 - 195.

[9] Brown, J. R and Day, R. L (1981) Measures of Manifest Conflict in Distribution Channels. Journal of Marketing Research. 18, $263 \quad-274$.

[10] Burke, R (2002) "Technology and the Customer Interface: What Consumers, Want in the Physical and Virtual Store". Journal Academy of Marketing Science, 30, 411 - 432.

[11] Cannon, J. P and Perreault, W. D. (1999) Buyer - seller Relationships in Business Markets. Journal of Marketing Research, 36, 439 - 460.

[12] Coca - Cola company (2008) http://sec.gov/Archivesledgar/data/.htm.

[13] Coughlan, A. T, Anderson , E. S, Stern, L. W. and El - Ansary, A. I (2006) Marketing Channels. Upper Saddle River, Pearson Prentice - Hall.

[14] Chwen, S. Hsiuju, R. Y and Bongsug, C. (2006) Determinants of Supplier - Retailer Collaboration: Evidence from an International Study. International Journal of Operations and Production Management 26, 144 - 357.

[15] Data monitor (2010). The Coca-cola Company: Company profile. http://search.ebscohost.com.lib.proxy.

[16] Danese, P. (2007) Designing Collaboration in Sights from Seven Cases. International Journal of Operations and Production Management, 27, 181 - 199.

[17] Dant, R. P. and Schul, P. L (1992) Conflict Resolution Processes in Contractual Channels of Distribution. Journal of Marketing 56, 38 - 54.

[18] Dholakia, U. Barbara, K, Randy, R, and Earl Taylor (2010) "Consumer Behaviour in a Multi-channel Multimedia Retailing Environment" Journal of Interactive Marketing.

[19] Donnelly, J. H and Peter, P. J. (2004) Marketing Management, Knowledge and Skills, New York, McGraw Hill Companies.

[20] Ehikwe, A (2002), Transportation and Distribution Management, Enugu, Precision Publishers.

[21] Falk, T. Jeroen, S and Hans, B (2007) "Identifying Cross-channel Dissynergies for Multi-channel Service Providers, "Journal of Service Research, 10, 143-160.

[22] Gaski, J. F. (1984). The Theory of Power and Conflict in Channels of Distribution. Journal of Marketing. $48,9-29$.

[23] Gensler, S. Dekimpe, M. G. and Skiera, B (2007) Evaluating Channel Performance in Multi-channel Environments "Journal of Retailing and Consumer Services", 14, 17 - 23.

[24] Glodkuhi, L. (2005), Multiple Marketing Channel Conflict with a focus on the Internet, Lulea, University Press.

[25] Gunasekarana, A. Patel, C. and McGaughey, R. E (2004). A Framework for Supply Chain Performance Measurement. International. Journal of Production Economics 87, 333 - 347.

[26] Grimm, M. (2000) Drink Me. American Demographics 22,62 - 63.

[27] Hibbard, J. D. Kumar, N and Stern, L. W. (2001) Examining the Impact of Destructive Acts in Marketing Channel Relationships. Journal of marketing Research, 38, 45-61.

[28] Jobber, D. (1008) Principles and Practice of Marketing, England, McGraw Hill Publishers. 
[29] Jonsson, P. and Gustavsson, M. (2008). The Impact of Supply Chain Relationship and Automatic Data Communication and Registration of Forecast Information Quality Distribution and Logistics Management 38, $607-610$.

[30] Konus, U. Peter and Scott, A. A. (2008) "Multi-channel Shopper Segments and their Covariates", Journal of Retailing, 84, 398 - 413.

[31] Kotler, P and Keller, K (2009) Marketing Management New Jersey, Pearson Prentice Hall.

[32] Kumar, V and Rajkumar, v (2005) "Who are the Multichannel shoppers and how do they perform? Correlates of Multichannel Shopping Behaviour", Journal of Interactive Marketing, 19, 44 - 61.

[33] Magrath, A. J. and Hardy, K. G. (1989). A Strategic Paradign for Predicting Manufacturer - Reseller Conflict, European Journal of Marketing. 23, 94-108.

[34] Morgan, R. M. and Hunt, S. D. (1994). The Commitment Trust Theory of Relationship Marketing. Journal of Marketing. 58, $20-38$

[35] Moriatry, R. T and Ursula, M. (1988) "Managing Hybrid Marketing Systems" Harvard Business Review.

[36] Muhwezi, M. (2008). Network Purchasing in Developing Countries. The case of Uganda. Journal of Global Business. 2. $30-45$.

[37] Palmatier, R. Dant, R. P. Grewal, D and Evans K. R. (2006) Factors Influencing the Effectiveness of Relationship Marketing. A Meta-Analysis. Journal of Marketing. 70, 136 - 153.

[38] Rangaswamy, A and Gerrit, B (2005) Opportunities and Challenges in Multi-channel Marketing: An Introduction to Special Issue". Journal of Interactive Marketing 19, 5 - 11.

[39] Rabinovich, E. and Bailey, J. P (2004). Physical Distribution Service Quality in Internet Retailing: Journal of Operation Management, 651 - 672.

[40] Rossenbloom, B. (2007) Multi-Channel Strategy in Business to Business Markets; Prospects and Problems. Industrial Marketing Management”, 36, 4-9.

[41] Savinhas, A. and Anderson, E. (2005) "How Potential Conflict Drives Channel Structure: Journal of Marketing Research. 42, 507 - 515.

[42] Sheth, J. N and Parvatiyar, A. (2000) Handbook of Relationship Marketing. Thousand Oaks. C. A. Sage Publications.

[43] Thomas, K. W (1992), Conflict and Negotiation Process in Organizations, a Handbook of Industrial and Organizational Psychology, Palo Alto, Consulting Psychologists Press.

[44] The Coca-cola Company (2010), Global Diversity Our Strategic Framework. Http://www//thecocacolacompany.com.

[45] Venus, L. Y., Chinshan, L and Kee-Hung, L (2009), Transport Logistics and Physical Distribution. International Journal of Production Economic1 -3

[46] Vereercke, A. and Muylle, S. (2006) Performance Improvement Through Supply Chain Collaboration in Europe. International Journal of Operations and Production Management 26, 1176 - 1182.

[47] Wang, S. and Archer, N (2007) Business to Business Collaboration Through Electronic Market Places: An exploratory Study. Journal of Purchasing and Supply Management. 13, 200 - 218.

[48] Wang, E. (2008). Study: Coke, the most talked about Brand in America. Brandweek 49, 38 - 39.

[49] Webb, K. L. and Hogan, J. E (2002) Hybrid Channel Conflict: Causes and Effect on Channel Performance: Journal of Business and Industrial Marketing, 17, 338 - 356.

[50] Webb, K. L. (2002) "Managing the Age of Distribution in the Economic Commerce", Industrial Marketing Management 31, $95-102$. 